\title{
QUALITY OF LIFE OF PEOPLE WITH DISABILITIES FROM SPORT PARTICIPATION POINT OF VIEW
}

\author{
Dagmar Nemček \\ Department of Sport Educology and Sport Humanities, Faculty of Physical Education and Sport, \\ Comenius University in Bratislava, Slovakia
}

Summary: The aim of the study was to compare the satisfaction with quality of life indicators (QoLI) and quality of life domains (QoLD) scores between people with physical disabilities (PPD) and people who are deaf or hard of hearing $(\mathrm{PD} / \mathrm{HH})$ from sport participation point of view. The study included 315 individuals with PPD $(\mathrm{n}=150$; male $=76)$ and PD/HH $(\mathrm{n}=165$; male $=85)$ divided into two groups of those who are regularly participating in sport and those who are not participating in any sport activity in their leisure. The second part of the Subjective Quality of Life Analysis (S.QUA.L.A.) was used. The Pearson chi-square test was used to determine the differences in 23 QoLI and 5 QoLD between PPD and $\mathrm{PD} / \mathrm{HH}$ from sport participation point of view and student's two-sample t-test was used to compare overall quality of life (QoL). We found that $\mathrm{PD} / \mathrm{HH}$ who are participating regularly in sport presented significantly higher satisfaction with 7 evaluated QoLI and with all 5 QoLD. Overall QoL score was significantly higher $(\mathrm{p}<.01)$ in $\mathrm{PD} / \mathrm{HH}$. In the group of people who are not participating in sport we found significantly higher satisfaction with $13 \mathrm{QoLI}$ in PD/HH and with 8 QoLI in PPD. Satisfaction with 4 QoLD was significantly higher in $\mathrm{PD} / \mathrm{HH}$ and only with domain (physical health) were significantly higher satisfied PPD $(\mathrm{p}<.01)$. Overall QoL score did not show significant differences between groups of people with disabilities who are not participating in any sport. The results of our study confirmed that $\mathrm{PD} / \mathrm{HH}$ have significantly higher QoL comparing PPD no matter if they participating in sport or not. This evaluation measured by S.QUA.L.A shows that it is a suitable tool to asses QoL in people with different kinds of disabilities.

Key words: people with physical disabilities, people who are deaf or hard of hearing, The Subjective Quality of Life Analysis, quality of life indicators and domains, participation in sport.

DOI 10.1515/afepuc-2016-0007

(C) Acta Facultatis Educationis Physicae Universitatis Comenianae 


\section{Introduction}

Participation in sports, whether competitive or non-competitive, is one way for people with disabilities to increase their quality of life (QoL). Some studies have argued that people with physical disabilities (Slater \& Meade, 2004; Ginis, Jorgensen \& Stapleton, 2012) and people who are deaf or hard of hearing who participate in sports and recreational activities (Nemček 2014; Nemček \& Kručanica 2014) improve self-confidence, self-esteem, and quality of life, as well as performance of activities of daily living (Kurková 2010; Kisvetrová et al. 2013).

Reviews of adults with various disabilities have described the physical, psychological, social, and economic benefits of participation in sports and recreational activities (Jackson \& Davis 1983; Klapwijk 1987; Shephard 1991; Hutzler \& Bar-Eli 1993; Richter, Gaebler-Spira \& Mushett 1996; Vanderstraeten \& Oomen 2010; Nemček, Labudová \& Kraček 2012; Dobay \& Bendíková, 2014; Nemček, Labudová \& Oršulová 2014; Bendíková, Jančoková \& Paugschová, 2015).

Many scientific papers suggest that participation in sports and recreational activities is beneficial to people with disabilities (Rimmer et al. 2010; Kurková, Válková \& Scheetz 2011; Bendíková, 2014; Kurková \& Maertin 2014). Tasiemski et al. (2005) performed a very large questionnaire-based study, including almost 1000 participants, in which about half were physically active or participated in organized sports. The participants were all wheelchair users. Those who participated in sports had a higher level of life satisfaction, along with a decreased depression and anxiety level. The overall conclusion was that the participants were satisfied with life in general, especially in social domains, but with the lowest satisfaction in sexual life and vocational situation. Sahlin \& Lexell (2015) present, that people with spinal cord injury who participate actively in sports display increased community integration, life satisfaction, employment, and extraversion, as well as decreased levels of anxiety and depression.

Many other investigators found an association between sports participation and QoL in people with disabilities. Buffart et al. (2008) performed a study that included 51 persons, aged $16-25$ years, with myelomeningocele and found an association between sports participation and social support, enjoyment of exercise, competence, self-perceived physical appearance, and global self-worth. Another questionnaire-based study with a total of 169 participants divided the subjects into 3 different groups based on their level of activity (Muraki et al. 2000). Sports participation appeared to decrease anxiety and depression, particularly in the 
group with the highest level of activity (active more than 3 times per week), although no significant differences were found (Tasiemski et al. 2000). This study provides an interesting baseline for the relevant frequency of activity for persons with spinal cord injury in order to maintain optimal psychological health. A pilot postal survey with 45 participants who had an spinal cord injury failed to find any significant correlations between participation in sports or leisure activities and the level of education or employment. People with a spinal cord injury kept being active in sports or other physical activities primarily to maintain good physical condition and improve upper body strength. Based on the articles reviewed, it is apparent that recreational either competitive sport can play an important role for people with disabilities. This also motivates further studies of sports participation as a way to increase health, function, QoL, and community integration.

Considering the previous research findings, the aim of our research was to compare satisfaction with QoL indicators (QoLI) and QoL domains (QoLD) between people with physical disabilities (PPD) and people who are deaf or hard of hearing ( $\mathrm{PD} / \mathrm{HH})$ within the group of people who participating regularly in sport and group of people who are not participating in any sport in their leisure. We hypothesized that satisfaction with the number of more than half of QoLI and with all QoLD will be significantly higher in $\mathrm{PD} / \mathrm{HH}$ comparing PPD within each assessed group.

\section{Methods}

\section{Participants and procedure}

Two groups of people with disabilities $(n=315)$ were recruited for the study: people with physical disabilities (PPD; $n=150)$, people who are deaf or hard of hearing $(\mathrm{PD} / \mathrm{HH} ; \mathrm{n}=$ 165). Both groups were divided to main two groups of participants: those who regularly participating in physical activity and sport at least two-time per week (PPD, $n=73 ; \mathrm{PD} / \mathrm{HH}, \mathrm{n}$ $=52)$ and participants who not participating in any sport in their leisure time (PPD, $\mathrm{n}=77$; $\mathrm{PD} / \mathrm{HH}, \mathrm{n}=113)$. Participants were contacted through representatives of national organisations and schools all around Slovakia unifying people with special needs. Some questionnaires were sent electronically by representatives of the organisations and some were passed out at the different meetings organised by national organisations. Pupils of special schools filled out the questionnaires during their classes with school principal permission. All data were collected during two years period (2013 - 2014). All participants with disabilities agreed participate in the study and gave their written informed consent. 


\section{The Subjective Quality of Life Analysis (S.QUA.L.A)}

S.QUA.L.A. is a multidimensional instrument. This multidimensional self-assessment method was created by Mathieu Zannotti in 1992 (Zannotti \& Pringuey 1992). This scale includes 22 items (indicators) of life. It covers traditional areas (food, family relation etc.), and more abstract aspects of life (politic, justice, freedom, truth, beauty and art, love). We used second part of S.QUA.L.A. where for each indicator, participants were asked to evaluate their degree of satisfaction using the 5-point rating scale. Score 1 (high satisfaction) meant the highest satisfaction and in the same time the highest level and score 5 (total disappointment) expressed the absolute insignificance of the particular indicator in life. For this study, we modified the S.QUA.L.A. questionnaire including one more indicator "sport participation" and we unified all 23 S.QUA.L.A. indicators into five domains following WHOQoL (WHO, 1997): (1) General health (GH); (2) Physical health and the Level of independence (PHLI); (3) Psychological health and Spirituality (PHS); (4) Social relationships (SR); Environment (E). In this study a Slovak version of the S.QUA.L.A. was used (Nemček et al., 2011).

\section{Data analyses}

Statistical analysis was performed using SPSS v. 15.0. Qualitative variables are presented as proportion and percentage. Quantitative variables are presented as mean. Pearson chi-square test was used to determine the differences in QoLI and QoLD between PPD and $\mathrm{PD} / \mathrm{HH}$ considering on the sport participation. Student's two-sample t-test was used to compare overall QoL between PPD and PD/HH from sport participation point of view. In current study, only one measurement has been made and two main groups of people with disabilities formed the study (people who regularly participated in sport and people who did not participate in any sport). The level of statistical significance was set at $p<.05$.

\section{Results}

\section{Participants}

Group of PPD $(\mathrm{n}=150)$ included individuals with following disabilities: $28.5 \%$ cerebral palsy, $28.2 \%$ amputees, $18.8 \%$ progressive muscular dystrophy, $17.9 \%$ spine cord injury (quadriplegia and paraplegia), $5.3 \%$ sclerosis multiplex and $1.3 \%$ myelomeningocele. Group of $\mathrm{PD} / \mathrm{HH}(\mathrm{n}=165)$ included $50.3 \%$ hard of hearing individuals and $49.7 \%$ deaf individuals. 
Table 1

Data of the 315 participants

\begin{tabular}{|c|c|c|c|c|c|}
\hline \multirow{3}{*}{\multicolumn{2}{|c|}{ Basic characteristics of participants }} & \multicolumn{2}{|c|}{$\begin{array}{c}\text { participating in sport } \\
n(\%)\end{array}$} & \multicolumn{2}{|c|}{$\begin{array}{c}\text { not participating in } \\
\text { sport } \\
\text { n }(\%) \\
\end{array}$} \\
\hline & & PPD & $\mathrm{PD} / \mathrm{HH}$ & PPD & $\mathrm{PD} / \mathrm{HH}$ \\
\hline & & $73(58.4)$ & $52(41.6)$ & $77(40.5)$ & $113(59.5)$ \\
\hline \multirow[t]{2}{*}{ Gender } & Men & $43(58.9)$ & $36(69.2)$ & $33(42.9)$ & $49(43.4)$ \\
\hline & Women & $30(41.1)$ & $16(30.8)$ & $44(57.1)$ & $64(56.6)$ \\
\hline \multirow[t]{2}{*}{ Age } & Range $15-29$ yrs & $41(56.2)$ & $21(40.4)$ & $34(44.2)$ & $30(26.5)$ \\
\hline & Range $30+$ yrs & $32(43.8)$ & $31(59.6)$ & $43(55.8)$ & $83(73.5)$ \\
\hline \multirow{3}{*}{ Education level } & Primary & $17(23.3)$ & $10(19.2)$ & $28(36.4)$ & $4(3.5)$ \\
\hline & High school & $41(56.2)$ & $38(71.2)$ & $35(45.5)$ & $99(87.7)$ \\
\hline & University & $15(20.5)$ & $4(7.7)$ & $14(18.1)$ & $10(8.8)$ \\
\hline \multirow[t]{4}{*}{ Merital status } & Single & $51(69.9)$ & $27(52.0)$ & $47(61.0)$ & $44(38.9)$ \\
\hline & Married & $16(21.9)$ & $23(44.2)$ & $19(24.7)$ & $58(51.3)$ \\
\hline & Divorced & $5(6.8)$ & $2(3.8)$ & $6(7.8)$ & $9(8.0)$ \\
\hline & Widow & $1(1.4)$ & $0(0)$ & $5(6.5)$ & $2(1.8)$ \\
\hline \multirow[t]{4}{*}{ Employment status } & Employed & $16(21.9)$ & $27(51.9)$ & $17(22.1)$ & $68(60.2)$ \\
\hline & Unemployed & $6(8.2)$ & $11(21.2)$ & $7(9.1)$ & $21(18.6)$ \\
\hline & Student & $34(46.6)$ & $10(19.2)$ & $31(40.2)$ & $7(6.2)$ \\
\hline & Pensioner & $17(23.3)$ & $4(7.7)$ & $22(28.6)$ & $17(15.0)$ \\
\hline
\end{tabular}

The highest number of participants who do not participating in sport showing the group of $\mathrm{PD} / \mathrm{HH}(59.5 \%)$ represented by women $(56.6 \%)$ over the 30 years of age $(73.5 \%)$. On the other hand, the highest number of individuals who are regularly participating in sport are represented by PPD (58.4\%) involving men (58.9\%) up to 29 years of age $(56.2 \%)$. The highest number of participants from all evaluated group have high school education level and mostly of them are single, except inactive $\mathrm{PD} / \mathrm{HH}$, where more than half of them are married (51.3\%). Individuals with physical disabilities (active as well as inactive) include more students comparing $\mathrm{PD} / \mathrm{HH}$, who are mostly employed. Basic participant's characteristics are presented in Table 1.

\section{S.QUA.L.A. and WHOQoL}

We found that PPD who are participating in sports are the most satisfied in their life with hobbies in leisure (1.945 points) and food (1.986 points) and the most dissatisfied with politics (4.000 points) and justice (3.423 points) (Table 2). $\mathrm{PD} / \mathrm{HH}$ who are participating in sports are the most satisfied in their life with love (1.824 points), family relations and food (1.846 points). QoLI like home environment (1.902 points), sleep (1.942 points), sexual activity (1.980 points) and sport in leisure with 1.904 points did not exceed 2 points of satisfaction, which means positive rating. The highest dissatisfaction in their life they presented with political situation (3.078 points). 
Table 2

Differences in QoLI between PPD and PD/HH who are participating in sport

\begin{tabular}{|l|c|c|c|c|}
\hline \multirow{2}{*}{ Indicators } & \multicolumn{2}{|c|}{ Mean } & \multirow{2}{*}{$\boldsymbol{\chi}^{\mathbf{2}}$} & \multirow{2}{*}{ sign. level } \\
\cline { 2 - 3 } & PPD & PD/HH & & \\
\hline Physical wellbeing & 2.616 & 2.154 & 11.99 & $\mathrm{p}<.01$ \\
\hline Psychological wellbeing & 2.110 & 2.212 & 1.688 & $\mathrm{~ns}$ \\
\hline Home environment & 2.041 & 1.902 & 3.657 & $\mathrm{~ns}$ \\
\hline Sleep & 2.205 & 1.942 & 3.764 & $\mathrm{~ns}$ \\
\hline Family relations & 2.042 & 1.846 & 7.923 & $\mathrm{~ns}$ \\
\hline Social relations & 2.027 & 2.096 & 2.553 & $\mathrm{~ns}$ \\
\hline Children & 2.038 & 2.038 & 2.711 & $\mathrm{~ns}$ \\
\hline Mobility/Daily activities & 2.239 & 2.038 & 8.913 & $\mathrm{~ns}$ \\
\hline Love & 2.444 & 1.824 & 11.32 & $\mathrm{p}<.05$ \\
\hline Sexual activity & 2.758 & 1.980 & 14.07 & $\mathrm{p}<.01$ \\
\hline Political situation & 4.000 & 3.078 & 27.53 & $\mathrm{p}<.01$ \\
\hline Religion/Spirituality & 2.301 & 2.580 & 13.67 & $\mathrm{p}<.01$ \\
\hline Rest in leisure & 2.167 & 2.019 & 4.201 & $\mathrm{~ns}$ \\
\hline Hobbies in leisure & 1.945 & 2.000 & 4.040 & $\mathrm{~ns}$ \\
\hline Sport in leisure & 2.342 & 1.904 & 7.933 & $\mathrm{~ns}$ \\
\hline Safety & 2.356 & 2.327 & 10.92 & $\mathrm{p}<.05$ \\
\hline Work/Education & 2.426 & 2.558 & 8.125 & $\mathrm{~ns}$ \\
\hline Justice & 3.423 & 2.731 & 16.92 & $\mathrm{p}<.01$ \\
\hline Freedom & 2.268 & 2.327 & 2.917 & $\mathrm{~ns}$ \\
\hline Beauty and art & 2.457 & 2.288 & 9.609 & $\mathrm{p}<.05$ \\
\hline Truth & 2.732 & 2.423 & 8.238 & $\mathrm{~ns}$ \\
\hline Finances & 2.870 & 2.500 & 5.716 & $\mathrm{~ns}$ \\
\hline Food & 1.986 & 1.846 & 2.039 & $\mathrm{~ns}$ \\
\hline t-test & $\mathbf{2 . 4 2 6}$ & $\mathbf{2 . 2 0 0}$ & $\mathbf{2 . 0 2 7}$ & $\mathbf{p}<. \mathbf{0 5}$ \\
\hline Possing
\end{tabular}

Possible indicator score range is $1-5$; lower mean scores indicate higher satisfaction with QoLI

The significant differences in satisfaction between PPD and $\mathrm{PD} / \mathrm{HH}$ who participating in sports in their leisure we found in eight QoLI: physical wellbeing $(p<.05)$, love $(p<.05)$, sexual activity $(\mathrm{p}<.05)$, political situation $(\mathrm{p}<.05)$, religion/spirituality $(\mathrm{p}<.05)$, safety $(p<.05)$, justice $(p<.01)$ and beauty and art $(p<.01)$. Significantly higher satisfaction with seven QoLI was presented by PD/HH and only with one indicator; "religion/spirituality" was in their life significantly satisfied actively living group of PPD. The mean scores show that $\mathrm{PD} / \mathrm{HH}$ are more satisfied in their life with 16 from 23 QoLI (69.6 \%) than PPD. Significantly higher level of overall QoL $(\mathrm{p}<.05)$ was presented by actively participating PD/HH in sport.

The WHOQoL general health $(\mathrm{p}<.01)$, physical health and level of independence $(\mathrm{p}<.01)$, psychological health and spirituality $(\mathrm{p}<.01)$, social relations $(\mathrm{p}<.01)$ and environment $(p<.01)$ scores were significantly higher in-group of $\mathrm{PD} / \mathrm{HH}$. The higher QoL level in PD/HH is represented also by the mean scores in all five QoLD (Table 3). 
Table 3

Differences in QoLD between PPD and PD/HH who are participating in sport

\begin{tabular}{|l|c|c|c|c|c|}
\hline \multirow{2}{*}{ Domains } & \multicolumn{2}{|c|}{ Mean } & \multirow{2}{*}{$\chi^{\mathbf{2}}$} & \multirow{2}{*}{ sign. level } \\
\cline { 2 - 4 } & PPD & PD/HH & & & \\
\hline GH & 2.822 & 2.250 & 13.51 & 0.008 & $\mathrm{p}<.01$ \\
\hline PHLI & 2.250 & 2.110 & 22.07 & $1.94 \mathrm{e}-4$ & $\mathrm{p}<.01$ \\
\hline PHS & 2.893 & 2.487 & 18.55 & $9.62 \mathrm{e}-4$ & $\mathrm{p}<.01$ \\
\hline SR & 2.216 & 1.990 & 19.08 & $7.56 \mathrm{e}-4$ & $\mathrm{p}<.01$ \\
\hline E & 2.304 & 2.160 & 37.13 & $1.69 \mathrm{e}-7$ & $\mathrm{p}<.01$ \\
\hline
\end{tabular}

PPD who are not participating in any sports in their leisure are the most satisfied in their life with home environment (1.948 points), food (1.974 points) and family relations (1.987 points) and the most dissatisfied with political situation (3.618 points), justice (3.416 points) and with sport in leisure (3.041 points) (Table 4). Inactive PD/HH presented the highest satisfaction with children (1.855 points), love (1.982 points) and family relations (1.991 points). On the other hand, they are the most dissatisfied with political situation (3.442 points), justice (3.116 points) and finances (3.063 points).

Table 4

Differences in QoLI between PPD and PD/HH who are not participating in sport

\begin{tabular}{|c|c|c|c|c|}
\hline \multirow{2}{*}{ Indicators } & \multicolumn{2}{|c|}{ Mean } & \multirow{2}{*}{$\boldsymbol{\chi}^{\mathbf{2}}$} & \multirow{2}{*}{ sign. level } \\
\cline { 2 - 3 } & PPD & PD/HH & & \\
\hline Physical wellbeing & 2.883 & 2.464 & 13.33 & $\mathrm{p}<.01$ \\
\hline Psychological wellbeing & 2.333 & 2.348 & 20.89 & $\mathrm{p}<.01$ \\
\hline Home environment & 1.948 & 2.259 & 23.51 & $\mathrm{p}<.01$ \\
\hline Sleep & 2.233 & 2.180 & 16.36 & $\mathrm{p}<.01$ \\
\hline Family relations & 1.987 & 1.991 & 23.28 & $\mathrm{p}<.01$ \\
\hline Social relations & 2.052 & 2.027 & 9.131 & $\mathrm{p}<.05$ \\
\hline Children & 2.226 & 1.855 & 14.04 & $\mathrm{p}<.01$ \\
\hline Mobility/Daily activities & 2.289 & 2.345 & 7.974 & $\mathrm{~ns}$ \\
\hline Love & 2.413 & 1.982 & 20.32 & $\mathrm{p}<.01$ \\
\hline Sexual activity & 2.826 & 2.027 & 33.56 & $\mathrm{p}<.01$ \\
\hline Political situation & 3.618 & 3.442 & 13.47 & $\mathrm{p}<.01$ \\
\hline Religion/Spirituality & 2.500 & 2.718 & 22.76 & $\mathrm{p}<.01$ \\
\hline Rest in leisure & 2.325 & 2.195 & 13.33 & $\mathrm{p}<.01$ \\
\hline Hobbies in leisure & 2.487 & 2.214 & 20.66 & $\mathrm{p}<.01$ \\
\hline Sport in leisure & 3.041 & 2.455 & 25.79 & $\mathrm{p}<.01$ \\
\hline Safety & 2.533 & 2.577 & 25.61 & $\mathrm{p}<.01$ \\
\hline Work/Education & 2.597 & 2.884 & 23.55 & $\mathrm{p}<.01$ \\
\hline Justice & 3.416 & 3.116 & 12.86 & $\mathrm{p}<.05$ \\
\hline Freedom & 2.566 & 2.429 & 10.80 & $\mathrm{p}<.05$ \\
\hline Beauty and art & 2.400 & 2.509 & 4.969 & $\mathrm{~ns}$ \\
\hline Truth & 2.844 & 2.679 & 16.90 & $\mathrm{p}<.01$ \\
\hline Finances & 2.776 & 3.063 & 22.31 & $\mathrm{p}<.01$ \\
\hline Food & 1.974 & 2.330 & 22.89 & $\mathrm{p}<.01$ \\
\hline t-test & $\mathbf{2 . 5 3 3}$ & $\mathbf{2 . 4 3 9}$ & $\mathbf{0 . 8 8 5}$ & $\mathbf{n s}$ \\
\hline
\end{tabular}

Possible indicator score range is 1-5; lower mean scores indicate higher satisfaction with QoLI 
The significant differences in satisfaction between PPD and $\mathrm{PD} / \mathrm{HH}$ who are not participating in sports were found in 21 from 23 QoLI. Significantly higher satisfaction with 13 QoLI (61.9\%) was presented by $\mathrm{PD} / \mathrm{HH}$ comparing PPD and on the other hand significantly higher satisfaction with 8 QoLI was declared by PPD (38.1\%) comparing $\mathrm{PD} / \mathrm{HH}$ in the evaluated group of population who are not participating in sport in their leisure. The mean scores show that PD/HH are more satisfied with more than half QoLI $(56.5 \%)$ comparing PPD who are showing higher satisfaction with 10 from 23 QoLI (43.5\%). Overall QoL comparison displays no significant differences between PPD and PD/HH who are not participating in sport in their leisure.

All WHOQoL present the level of statistical significance in the group of population who are not physically active in their leisure. General health $(\mathrm{p}<.05)$, psychological health and spirituality $(\mathrm{p}<.01)$, social relations $(\mathrm{p}<.01)$ and environment $(\mathrm{p}<.01)$ scores were significantly higher in group of $\mathrm{PD} / \mathrm{HH}$, whereas QoLD "physical health and level of independence" scores showing significantly higher satisfaction in PPD (Table 5).

Table 5

Differences in QoLD between PPD and PD/HH who are not participating in sport

\begin{tabular}{|l|c|c|c|c|c|}
\hline \multirow{2}{*}{ Domains } & \multicolumn{2}{|c|}{ Mean } & \multirow{2}{*}{$\boldsymbol{\chi}^{\mathbf{2}}$} & \multirow{2}{*}{$\boldsymbol{p}$} & sign. level \\
\cline { 2 - 4 } & PPD & PD/HH & & & \\
\hline GH & 3.000 & 2.637 & 10.66 & 0.034 & $\mathrm{p}<.05$ \\
\hline PHLI & 2.376 & 2.392 & 50.57 & $2.27 \mathrm{e}-10$ & $\mathrm{p}<.01$ \\
\hline PHS & 2.865 & 2.741 & 55.16 & $3.01 \mathrm{e}-11$ & $\mathrm{p}<.01$ \\
\hline SR & 2.272 & 1.975 & 64.44 & $3.38 \mathrm{e}-13$ & $\mathrm{p}<.01$ \\
\hline E & 2.559 & 2.499 & 83.63 & $5.58 \mathrm{e}-15$ & $\mathrm{p}<.01$ \\
\hline
\end{tabular}

\section{Discussion}

Disability affects the satisfaction with health, the ability of independent functioning, ability to work and earn for a living, the ability to have and raise children, and achieving partnerships. Own body image, self-concept and self-esteem can be significantly altered as a result of a disability (Janeković 2003). All of these factors may contribute to a lower QoL for people with disabilities. Some studies have shown poor QoL for people with physical disability (Dijkers 1997; Post et al. 1998). Others have shown disabled people to be more satisfied in some aspects of life, while less satisfied in others than people without disabilities.

The current study presents that PPD, no matter if they participating in sports or not, are the most satisfied in their life with hobbies in leisure, food, home environment and family 
relations. Another research points to the most frequent QoLI named by PPD as family, work and finance, hobbies, health, relationship with friends and job effectiveness (Mattarozzi et al. 2016).

On the other hand $\mathrm{PD} / \mathrm{HH}$, no matter if they participating in sports or not, presenting in the current study the highest satisfaction with more QoLI than PPD like love, family relations, children, food, home environment, sleep, sexual activity and sport in leisure. Health-related measures of QoL based on physical, emotional, and psychological functioning have been reported for persons who are D/HH (Hawthorne et al. 2004; Huber 2005; Karinen et al. 2001; Wake et al. 2004), but just few studies measured the QoL relating to sport participation in this target group of population. Nemček \& Kručanica (2014) assessed the QoL in 152 participants who are deaf or hard of hearing and found that people with hearing impairments involved in sport show significantly higher satisfaction with physical health and the level of independence, psychological health and spirituality and presented significantly higher satisfaction with general health comparing the individuals with hearing impairment who lead sedentary lifestyle. Nemček (2014) found that, the individuals with hearing impairments are more satisfied with physical health and the level of independence than psychological health and spirituality. In other study, general life satisfaction in $\mathrm{PD} / \mathrm{HH}$ youth was found to be significantly lower in the areas of self, family, friends, and living environment compared with controls that had normal hearing (Gilman, Easterbrooks \& Frey 2004). Kurková \& Maertin (2014) and Kurková (2015) point to positive emotional reactions of physical activities in leisure and physical education classes in students in schools for the deaf who showed the highest values among the three evaluated groups of students (students who are deaf or hard of hearing integrated in general schools and hearing classmates). It can become a tool to increase the popularity of physical and sport activities at the same time become a regular part of youth's leisure activities that can lead to increase their QoL through regular participation in sport in later life (Kurková, Nemček \& Labudová 2015; Kurková, Scheetz \& Stelzer 2010).

The current study further presents smaller number of significant differences in QoLI (34.8\%) between people with different kinds of disabilities (PPD and PD/HH) who are regularly participating in sport activities in their leisure time. Different results were presented in QoLD comparison, where the satisfactions with all five QoLD were significantly higher in the group of $\mathrm{PD} / \mathrm{HH}$ as well as the assessment of overall QoL. 
On the other hand, the current study presents very high number of significant differences in QoLI between PPD and PD/HH who are not participating in any sport $(91.3 \%)$. Significantly higher satisfaction with $61.9 \%$ was presented by $\mathrm{PD} / \mathrm{HH}$ and with $38.1 \%$ by PPD. Similar results are presented in evaluation of QoLD, when satisfaction with four from five assessed QoLD were significantly higher in PD/HH and only with one QoLD were significantly more satisfied in their life group of PPD. Overall QoL comparison displays no significant differences between PPD and PD/HH who are not participating in sport in their leisure.

The research paper of Nemček et al. (2014) present, that there are no significant differences in most of the QoLI between active and inactive individuals with physical disabilities (PD). Only three from 23 QoLI showing significantly higher satisfaction in active people with PD. Similar results are resented in evaluation of QoLD, when only one from five assessed domains is significantly higher in active people with PD. Even overall QoL in mentioned study doesn't displays significant differences between active and inactive individuals with PD, but authors say, that active people with PD are generally more satisfied with their life and present higher QoL than inactive peers what is showed by mean score of each evaluated QoLI (15 from 23) as well as QoLD (4 from 5). The research paper of Nemček et al. (2014) further presents bigger number of significant differences in QoLI between active and inactive people who are deaf or hard of hearing $(\mathrm{D} / \mathrm{HH})$ comparing active and inactive individuals with PD. Ten form 23 QoLI showing significantly higher satisfaction in active people who are D/HH comparing their inactive peers. Similar results in the same study were presented in evaluation of QoLD, when four from five assessed domains are significantly higher in active people who are $\mathrm{D} / \mathrm{HH}$ as well as overall QoL was significantly higher in active people who are $\mathrm{D} / \mathrm{HH}$. Comparing the QoL between active and inactive people who are D/HH authors say, that active participants are more satisfied with their life than inactive peers who are D/HH what was presented by QoLI, QoLD as well as by overall QoL assessment.

Based on current scientific evidence we couldn't confirm the hypothesis, where we assumed, that satisfaction with more than half of QoLI and with all QoLD will be significantly higher in $\mathrm{PD} / \mathrm{HH}$ comparing PPD within both evaluated groups of people (who are regularly participating in sport and who are not participating in sport in leisure). Although significantly higher satisfaction with $61.9 \%$ QoLI was presented by PD/HH comparing PPD in the group of population who not participating in any sport as well as significantly higher satisfaction with all five QoLD were declared by $\mathrm{PD} / \mathrm{HH}$ who are physically active in their 
life, but evaluation of QoLI differences in the group of people who are regularly participating in sports as well as assessment of QoLD in the group of people who are not participating in sport did not confirmed out assumption. $\mathrm{PD} / \mathrm{HH}$ who are participating in sport regularly are significantly more satisfied only with seven QoLI (30.4 \%) and PD/HH who are not involved in any sport in their leisure are significantly satisfied with four from five QoLD (80\%).

\section{Conclusion}

Based on the aim of the current study, we found that:

- PPD are the most satisfied in their life with hobbies in leisure, food, home environment and family relations and $\mathrm{PD} / \mathrm{HH}$ with love, family relations, children, food, home environment, sleep, sexual activity and sport in leisure.

- PPD showed the highest dissatisfaction with politics, justice and sport in leisure and $\mathrm{PD} / \mathrm{HH}$ with political situation, justice and finances.

- The significant differences in satisfaction between PPD and PD/HH who participating in sports in their leisure we found in eight QoLI where with seven are significantly higher satisfied $\mathrm{PD} / \mathrm{HH}$.

- The significant differences in satisfaction between PPD and PD/HH who are not participating in sports were found in 21 from 23 QoLI where with 13 are significantly higher satisfied $\mathrm{PD} / \mathrm{HH}$.

- Significantly higher level of overall QoL was presented by PD/HH who are actively participating in sport and no significant differences in overall QoL between inactive $\mathrm{PPD}$ and $\mathrm{PD} / \mathrm{HH}$.

- With all five QoLD are significantly higher satisfied PD/HH who are participating in sport and group of $\mathrm{PD} / \mathrm{HH}$ who are not participating in sport are significantly higher satisfied with four QoLD.

- QoLD "physical health and level of independence" scores showing significantly higher satisfaction in PPD who are not participating in sport.

Generally we can say, that the evaluation of the satisfaction with QoLI and QoLD by S.QUA.L.A. shows that it is a suitable tool to asses QoL in the population with different kinds of disabilities. The results of our study, mean scores as well as level of significance confirmed, that $\mathrm{PD} / \mathrm{HH}$ are more satisfied with their life represented by QoLI and QoLD than PPD independently from sport participation. We recommend, that it is essential to increase participation in sports, because such participation can empower people with disabilities to set 
and attain goals and reach a higher QoL on their own terms.

\section{References}

1. BENDÍKOVÁ, E., 2014. Lifestyle, physical and sports education and health benefits of physical activity. In: European Researcher : International Multidisciplinary Journal. 69(2), pp. 343-348.

2. BENDÍKOVÁ, E., L. JANČOKOVÁ \& B. PAUGSCHOVÁ, 2015. Risk factors of health in lifestyle of adults. In: Sport Science. 8(2), pp. 44-48.

3. BUFFART, L.M., H.P. VAN DER PLOEG, A.E. BAUMAN, F.W. VAN ASBECK, H.J. STAM, M.E. ROEBROECK \& R. VAN DEN BERG-EMOS, 2008. Sports participation in adolescents and young adults with myelomeningocele and its role in total physical activity behaviour and fitness. In: Journal of Rehabilitation Medicine. 40(9), pp. 702-708.

4. DIJKERS, M., 1997. Quality of life after spinal cord injury: A meta analysis of the effects of disablement components. In: Spinal Cord. 35(12), pp. 829-840.

5. DOBAY, B. \& E. BENDÍKOVÁ, 2014. Športové a rekreačné aktivity v životnom štýle dospelých. [Sports and recreational activities in the lifestyle of adults]. In: BENCE, M. \& P. PIVOVARNIČEK, Slovak journal of sport science. Univerzita Mateja Bela v Banskej Bystrici, Banská Bystrica, pp. 19-31.

6. GILMAN, R., S.R. EASTERBROOKS \& M. FREY, 2004. A preliminary study of multidimensional life satisfaction among deaf/hard of hearing youth across environmental settings. In: Soc. Indic. Res. 66(1-2), pp. 143-164.

7. GINIS, M.K.A., S. JORGENSEN \& J. STAPLETON, 2012. Exercise and sport for persons with spinal cord injury. In: PM\&R: The Journal of Injury, Function and Rehabilitation. 4(11), pp. 894-900.

8. HAWThORNe, G, A. HOGAN, E. Giles, L. KETHEL, K. White, B. PlAith, K. PEDLEY, E. RUSHBROOKE \& A. TAYLOR, 2004. Evaluating the health-related quality of life effects of cochlear implants: a prospective study of an adult cochlear implant program. In: International Journal of Audiology. 43(4), pp. 183-192.

9. HUBER, M., 2005. Health related quality of life of Austrian children and adolescents with cochlear implants. In: Interantional Journal of Pediatric Otorhinolaryngology. 69(8), pp. 1089-1101.

10. HUTZLER, Y. \& M. BAR-ELI, 1993. Psychological benefit of sports for disabled people: A review. In: Scandinavian Journal of Medicine \& Science in Sports. 3(4), pp. 217-228. 
11. JACKSON, R.W. \& G.M. DAVIS, 1983. The value of sports and recreation for the physically disabled. In: The Orthopaedic Clinics in North America. 14(2), pp. 301-315.

12. JANEKOVIĆ, K., 2003. Comparative research on substance abuse and self-perception among adolescents with physical handicap. In: Collegium Antropologicum. 27(2) pp. 479489.

13. KARINEN, P.J., M.J. SORRI, T.T. VALIMAA, K.H. HUTTUNEN \& H.J. LÖPPÖNEN, 2001. Cochlear implant patients and quality of life. In: Scandinavian Audiology. 1(52), pp. 48-50.

14. KISVETROVÁ, H., P. KURKOVÁ, B. ŠVEJdÍKOVÁ \& R. POPELKOVÁ, 2013. Používání sluchadla jako aspekt kvality života seniorské populace. [Using the deaf-aid as the aspect of senior's quality of life]. In: MURGAŠ F. Kvalita života 2013. Sborník př́spěvki̊ z medzinárodní conference. [Quality of Life 2013, Proceedings of the International Conference]. Technical University in Liberec, Liberec, pp. 53-62.

15. KLAPWIJK, A., 1987. The multiple benefits of sports for the disabled. In: International Disability Studies. 9(2), pp. 87-89.

16. KURKOVÁ, P., 2010. Vzděláváni žákỉ se sluchovým postižením z hlediska vedeni ke zdravému životnímu stylu. [The education of pupils who are deaf or hard of hearing from guiding to healthy life style point of view]. Olomouc: Palacky University in Olomouc, ISBN 978-80-244-2582-5.

17. KURKOVÁ, P. 2015. Emotions in the physical activi ties of Czech students who are deaf or hard of hearing in general and special education. In: Journal of Physical Education and Sport. 15(4), pp. 823-828.

18. KURKOVÁ, P. \& J.J. MAERTIN, 2014. The benefits of square dancing as a means of physical activity for Czech dancers with hearing loss. In: Acta Gymnica. 44(4), pp. $223-$ 230.

19. KURKOVÁ, P., D. NEMČEK \& J. LABUDOVÁ, 2015. Pupils with sensory disabilities in physical education classes: Attitudes and preferences. In: Acta Gymnica. 45(3), pp. $139-145$.

20. KURKOVÁ, P., H. VÁLKOVÁ \& N. SCHEETZ, 2011. Factors impacting participation of European elite deaf athletes in sport. In: Journal of Sports Sciences. 29(6), pp. 607618.

21. KURKOVÁ, P., N.A. SCHEETZ, \& J. STELZER, 2010. Health and physical education as an important part of school curricula: A comparison of schools for the deaf in the Czech 
Republic and the United States. In: American Annals of the Deaf. 155(1), pp. 78-87.

22. MATTAROZZI K., F. CASINI, E. BALDIN, M. BALDINI, A. LUGARESI, P. MILANI, E. Pietrolongo, A. GAjofatto, M. LeOne, T. RiISE, L. VignAtelli \& R. D'ALESSANDRO, 2016. Assessing subjective quality of life domains after multiple sclerosis diagnosis disclosure. In: Health Expectations: An International Journal of Public Participation in Health Care and Health Policy. 19(2), pp. 437-447.

23. MURAKI, S., N. TSUNAWAKE, S. HIRAMATSU \& M. YAMASAKI, 2000. The effect of frequency and mode of sports activity on the psychological status in tetraplegics and paraplegics. In: Spinal Cord. 38(5), pp. 309-314.

24. NEMČEK, D., 2014. Spokojnost' so sociálnymi vzt’ahmi a prostredím ako súčast' kvality života l’udí so sluchovým postihnutím z pohl'adu športovania vo vol’nom čase. [Satisfaction with Social Relations and Environment as Parts of the Life Quality of People who are Deaf or Hard of Hearing from the Point of View of Leisure Sports]. In: KRAJČOVIČOVÁ Z., V. MELUŠ, E. KRÁLOVÁ \& L. KRÁL, Pohyb a zdravie XI: Pohybová aktivita a zdravý životný štýl-Šport a športový tréning. [Movement and Health XI: Physical Activity and Healthy Life Style - Sports and Sport Training]. Trenčianska Univerzita A. Dubčeka, Trenčín, pp. 110-116.

25. NEMČEK, D. \& L. KRUČANICA, 2014. Satisfaction with health status in people with hearing impairments. In: SCHICKHOFER, P. \& G. BUZGÓ. Sports, Physical Activity and Health 2014, International Scientific Conference. Comenius University in Bratislava, Bratislava, pp. 185-191.

26. NEMČEK, D., J. LABUDOVÁ, T. JAVANAINEN-LEVONEN \& J. WITTMANNOVÁ, 2014. Quality of life between active population and population with sedentary behavior with different health status. In: EUCAPA European Congress of Adapted Physical Activity. Universidad politécnica de Madrid. Madrid, pp. 1.

27. NEMČEK, D., J. LABUDOVÁ \& S. KRAČEK, 2012. Life satisfaction of sedentary and physically active population. In: Acta Facultatis Educationis Physicae Universitatis Comenianae. 52(1), pp. 61-71.

28. NEMČEK, D., J. LABUDOVÁ \& N. ORŠULOVÁ, 2014. Self-esteem in people with disabilities. In: Acta Facultatis Educationis physicae Universitatis Comenianae. 54(2), pp. $33-42$.

29. NEMČEK D, J. LABUDOVÁ, J. PERÁČKOVÁ, E. BENDÍKOVÁ, H. MEDEKOVÁ, A. PAVLÍKOVÁ, S. KRAČEK, M. BARDIOVSKÝ \& S. HREBÍKOVÁ, 2011. Kvalita 
života seniorov a pohybová aktivita ako jej súčast'. [Quality of life in seniors and physical activity as a part of it]. Bratislava: Michal Vaško Vydavatel'stvo Prešov. ISBN 978-807165-857-3.

30. POST M.W.M., A.J. VAN DIJK, F.W.A. VAN ASBECK \& A.J.P. SCHRIJVERS, 1998. Life satisfaction of spinal cord injured compared to a population group. In: Scandinavian Journal of Rehabilitation Medicine. 30(1), 23-30.

31. RICHTER, K.J., D. GAEBLER-SPIRA \& C.A. MUSHETT, 1996. Sport and the person with spasticity of cerebral origin. In: Developmental Medicine and Child Neurology. 38(9), pp. 867-870.

32. RIMMER, J.H., CH. MING-DE, J.A. McCUBBIN, CH. DRUM, \& J. PETERSON, 2010. Exercise intervention research on persons with disabilities: what we know and where we need to go. In: American Journal of Physical Medicine \& Rehabilitation. 89(3), pp. 249263.

33. SAHLIN, K.B. \& J. LEXELL, 2015. Impact of Organized Sports on Activity, Participation, and Quality of Life in People with Neurologic Disabilities. In: $P M \& R$ : The Journal of Injury, Function and Rehabilitation. 7(10), pp. 1-8.

34. SHEPHARD, R. 1991. Benefits of sport and physical activity for the disabled: Implications for the individual and for society. In: Scandinavian Journal of Rehabilitation and Medicine. 23(2), pp. 51-59.

35. SLATER, D. \& M.A. MEADE, 2004. Participation in recreation and sports for persons with spinal cord injury: Review and recommendations. In: NeuroRehabilitation. 19(2), pp. 121-129.

36. TASIEMSKI, T., E. BERGSTROM, G. SAVIC \& B.P. GARDNER, 2000. Sports, recreation and employment following spinal cord injury: Pilot study. In: Spinal Cord. 38(3), pp. 173-184.

37. TASIEMSKI, T., P. KENNEDY, B.P. GARDNER \& N. TAYLOR, 2005. The association of sports and physical recreation with life satisfaction in a community sample of people with spinal cord injuries. In: NeuroRehabilitation. 20(4), pp. 253-265.

38. VANDERSTRAETEN, G.G. \& A.G. OOMEN, 2010. Sports for disabled people: A general outlook. In: International Journal of Rehabilitation Research. 33(3), pp. 283-284.

39. WAKE, M., E.K. HUGHES, C.M. COLLINS \& Z. POULAKIS, 2004. Parent-reported health-related quality of life in children with congenital hearing loss: A population study. In: Ambulatory Pediatrics. 4(5), pp. 411-417. 
40. WHO, 1997. WHOQOL Measuring Quality of Life: Program on Mental Health [online]. December 1997 [cit. 2016-04-15]. Accessible from:

http://www.who.int/mental_health/media/68.pdf

41. ZANNOTTI, M. \& D. PRINGUEY, 1992. A method for quality of life assessment in psychiatry: The S-QUA-L-A (Subjective QUAlity of Life Analysis). In: Quality of Life News Letter. 4(6). 